\title{
Impact of NPA on Profitability of Banks
}

\author{
Dr. Ritu Wadhwa ${ }^{1}$, Mr. Kartik Ramaswamy2 \\ ${ }^{1}$ Assistant Professor, Amity University, Uttar Pradesh \\ ${ }^{2}$ Student-MBA Fin, Amity University, Uttar Pradesh \\ (E-mail:rwadhwa1@amity.edu) \\ (E-mail: kartik.ramaswamy96@gmail.com)
}

\begin{abstract}
The main source of growth for Indian Economy is Banks. Everyone has different needs like someone require loan to buy a house, to buy an equipment for farming etc. and these needs are fulfilled by the financial sector of India which comprises of banks, NBFC, cooperative societies etc. NPA (Non-Performing Asset) is a critical factor which has adversely impacted the development and growth of the economy. This research discusses the impact of NPAs on the profits of banks. This research attempts to analyze the impact of few important financial heads on NPAs of banks and to suggest on effective management of NPAs. According to RBI data, five banks (public and private) with highest NPAs were taken for the study for period 2014-2015 to 2018-2019. The research applied correlation analysis to compute the relationship between net profits and NPAs and multiple regression analysis to determine the impact of important financial heads on NPAs.
\end{abstract}

Keywords - Non-Performing Asset, Net Profits, Key Financial Heads, Correlation Analysis, Multiple Regression

\section{Introduction}

It has been contended by various market analysts that a good financial system provides an easy flow of reserve funds which eventually help in financial development. Many economists are of the view that a good economic growth needs to be supported by a good financial system which would ensure easy flow credit and also credit creation. A sound financial system can help in accomplishing proficient distribution of assets by minimizing the issues arising due to market erosions etc. Among the various known qualities of a well-working financial system, the support of a couple of NPAs is a significant one. However NPAs beyond a particular level becomes a matter of concern for everyone. NPAs affect the flow of credit which in turn affect the development and growth of the economy hence proper flow of credit is the need of the hour. Banks not only raise assets through new deposits but they also reuse the assets which they get from the borrowers. Thus, when a customer do not return the money thereby creating a NPA, it affects credit creation and reuse of credit. Besides this, NPAs affects the profits earned by the banks as they have to create bigger provisions for doubtful and bad debts. In this way, the issue of NPAs is not only a worry for the lenders but also a worry for strategy makers too who are involved in contributing financial development on the road to success.

The financial sector in India went through lot of modifications and the idea of NPA was introduced in India based on the suggestions given by the Narasimham Committee in 1991 which was followed up by setting up of a proper accounting system. ${ }^{[14]}$

\section{A. Meaning of NPA}

Reserve Bank of India has provided guidelines for determining when an asset becomes NPA.

1. If interest/instalment of principal with respect to Term Credit is due for more than ninety days, it is considered as NPA.

2. If Overdraft/Cash Credit (OD/CC) amount is persistently greater than the sanctioned limit for more than ninety days then it is considered as NPA.

3. If the overdue bills purchased and discounted exceed ninety days then it is a non-performing asset.

4. If interest/instalment of principal with respect to agriculture advances is due for two harvest seasons but the duration is not surpassing two terms of six months on account of advance granted, then it is considered as NPA.

5. Any receivable amount that is due for more than ninety days in regard of other accounts, then it is considered as NPA.

\section{B. Factors responsible for NPA}

1. Diversification of funds for purposes other than actual.

2. Decline of business because of failure in product/marketing as well as failure in financial administration, stressed work relations, selection of unseemly innovation, utilizing obsolete hardware, specialized issues and outdated products. 
Website: ijetms.in Issue:3, Volume No.4, May-2020 DOI: 10.46647/ijetms.2020.v04i03.001

3. Economic downturn, input deficiency, power shortage, price escalation, mishaps, natural calamities and issues with clients leading to non-payment of over dues.

4. Over run cost and time during project implementation stage.

5. Frequent change in Government policies like changes in pollution control standards, excise duties, poor credit choices, priority sector lending and legal system.

6. Wilful default, redirecting assets, extortion and misappropriation of funds.

\section{Classification of NPA}

For the purpose of making provision for NPAs, different advances of a bank are classified into four categories with variable provision, as explained in detail below.

1. The assets in which the risk associated with them is just the basic risk which is associated with every business and also they don't have any issue are termed as Standard Assets. Earlier no provisions was required on standard assets. However from 31.3.2003, a $0.25 \%$ provision needs to be created by the banks on standard assets on the basis of global loan portfolio basis.

2. Assets which are non-performing asset and not exceeding two years are termed as Sub-standard assets. However from 31.03.2001, sub-standard assets are those assets that have remained as non-performing asset for less than 18 months. In such scenarios, it is not possible for the banks to recover all the dues from the customer as the current market value of the asset or net worth of the borrower/ guarantor is not enough. It means that if the anomalies are not rectified then such assets will have a credit gap and this will hamper the liquidation of debt and thus there are chances of some loss that has to be borne by the banks. A $10 \%$ provision of the total outstanding amount has to be made in case of sub-standard assets.

3. Assets which are non-performing asset and have exceeded two years are termed as Doubtful Assets. However from 31.03.2001, doubtful assets are those assets that are nonperforming asset and exceeding 18 months (1.5 years). All the components of sub-standard assets are present in Doubtful assets along with the additional components. There are two components for provision in respect of doubtful debts. They are as per the following:

a. If a part of debt is not covered by the attainable market price of the asset then a hundred percent provision has to be made for that part. b. In addition to the above (a) for the secured portion of the doubtful assets, depending upon the duration of the doubtful asset, a provision ranging from $20 \%$ to $50 \%$ will be made.

4. Loss Assets are those losses which are recognized by the bank, auditors or through inspection conducted by the RBI however the entire amount has not been discounted. It means that the asset with the bank is not worthy or its worth is so less that it cannot be considered as an asset even though it might have some recovery value associated with it. The whole asset ought to be discounted. In such scenarios, the asset is kept in the books and hundred percent of the 'net book value' ought to be given.

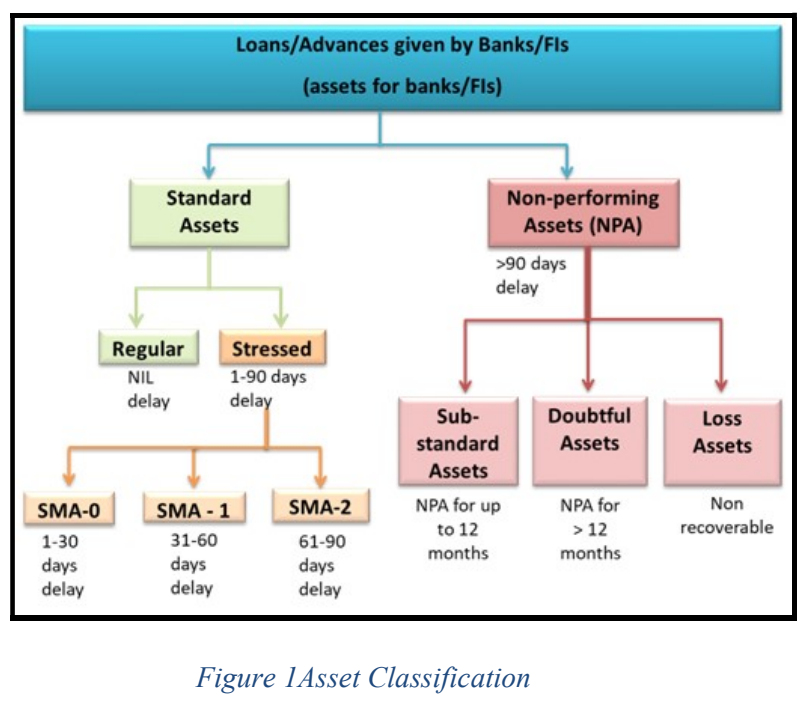

D. Impact of NPA

1. Profitability: The profits and NPAs are inversely proportional. With increase in NPA, there will be decrease in profits because the banks do not receive the payments and along with this the banks also need to create bigger provisions according to the type of NPA. Usually banks create provision ranging from $20 \%$ to $50 \%$.

2. Credit contraction: With increase in the NPAs, funds are not easily reused causing a decrease in the lending capacity of banks thereby decreasing the income of the banks. A monetary log jam may be caused if the NPAs contract the cash stock.

3. Liability Management: With rise in NPAs, the interest rates of deposits will be reduced by the banks and interest rates on loans will be increased in order to maintain net 
Website: ijetms.in Issue:3, Volume No.4, May-2020 DOI: 10.46647/ijetms.2020.v04i03.001

interest margin. This may cause hindrance in the overall functioning of financial sector as customers will not easily get loans and even if they get it, they may have to pay high interest and this will hampers the banks business and also economic growth.

4. Shareholders' confidence: Usually shareholders are mainly concerned about gaining higher dividends on their investments. However if the banks have high NPAs then the profits earned by the banks are very less which in turn means that the shareholders might get very low dividends and in some case they may lose out on their investment. The banks are required to obtain an approval from the RBI before declaring the dividend if the banks have net NPA level at $5 \%$ or more

5. Public certainty: With rise in NPA, the population starts questioning the credibility of the banks and may show resistance which in turn will cause liquidity issue in banks as people may not invest or deposit money in the banks.

Thus rising NPAs is neither good for the banks as it hampers their profits nor it is good for economy.

\section{E. Key Financial Heads}

1. Total Assets is defined as "sum of current and long term assets owned by a person, company or other entity".

2. Total Deposits is defined as the "money deposited in a bank for safety".

3. Total Advance is defined as "loan given by a bank to a customer, against the security of an asset".

\section{REVIEW OF LITERATURE}

In [1] it was highlighted that ROA is negatively related to NPA. It showed that ownership had significant influence on the NPAs i.e. there was higher NPAs in public sector. The research also explained that the banks possess assets of deteriorating quality which eventually have an adverse impact on the economy. In [2] it showed the impact of important financial heads on the NPAs. The research was conducted using multiple regression and suggested that banks should try to manage Total Assets (TA) and Total Deposits (TD) for reducing future NPAs and managing existing ones. In [3] a brief about NPA was given. The research was done to check whether profitability is related to NPA. The research also determined how the profits of banks are affected due to NPA. It suggested that NPAs cannot completely be removed but it is possible to control it. In [4] it emphasized on the fact that NPAs not only affect the financial institutions but overall financial system gets affected. The study was performed on selected banks to assess changes in the bank's profit due NPAs. The study also suggested that now the assets possessed by banks will be assessed along with other factors viz. Deposits, number of branches etc. In [5] the impact of gross Non -Performing Assets/gross advances ratio on net profit (total assets \%) was explained with help of linear regression. The statistical significance was tested using t-statistics and the fitness of the model was tested using F-statistic.

In [6], it explained about the various provisions the banks are required to create with respect to different asset class. In the research, multiple regression was used to examine the impact of the selected financial ratios on NPA. The lending in the priority sector has been a positive for public banks however it suggested that the transaction costs should be reduced in order to increase the profits. In [7] a research was conducted on the data of scheduled commercials banks which was taken for ten years. The study was conducted using ratio analysis and regression analysis. It suggested that NPAs and profits are inversely related. In [8] an overview of the NPA scenario sector wise was given. The research also suggested the ways through the banks can recover and reduce NPAs. The research also examined the overall impact of NPA on the banking sector of India. The research showed that there has been an uptrend in NPAs in the last few years and suggested that the banks must be agile and proactive while selecting their clients before lending them. The causes of NPAs was examined and its impact was analyzed in [9]. The research explained about the classification of NPAs and also suggested the ways to recover from NPA through various channels. The research suggested that banks should be more proactive and take stringent measure and consider the ROI or credit score of customers before lending them. In [10] it was highlighted that with increase in the credit in the economy, there has been an uptrend in the NPAs of banks. It also gave an overview of the various factors responsible for NPAs. The research was conducted to analyze the relation of share price and NonPerforming Asset (NPAs). The research showed that there was a strong relation between share price and NPAs in case of private banks however it differed for public banks.

In [11] it highlighted the current scenario of NPAs in India. The data was collected for three years and correlation and trend analysis was performed. The research showed a negative correlation between profits and NPAs. In [12] it highlighted the status of NPA of banks in India and also suggested various ways through which banks can handle the existing NPAs and avoid future NPAs from occurring. The research also explained the impact of NPA on various factors like shareholder's confidence, capital adequacy etc. The research suggested various ways like technical write offs, one time settlement scheme, recovery camps etc. to reduce NPAs. [13] explained that the profits earned by bank is impacted by many factors. The research compared the important factors of profits for SBI and HDFC bank and it was seen that in case of SBI, 
Website: ijetms.in Issue:3, Volume No.4, May-2020 DOI: 10.46647/ijetms.2020.v04i03.001

business per employee was the key determinant for profit while bank size and advances were the determinants in case of HDFC bank. In [14] it explained that due to NPAs the credit creation and recycling of credit gets adversely. The research gave an overview of the Narasimham Committee Report, 1991 which gave many recommendations to be implemented in the financial sector. In [15] a diagnostic and exploratory research was performed with an effort to analyze the loan assets composition in banks. In the research the data was collected for five years for the amount of composition of loan assets (sub-standard, doubtful, loss). The research showed that substandard assets were high in banks (public and foreign) while doubtful assets were high in private banks.

\section{RESEARCH METHODOLOGY}

\section{A. Statement of the Problem}

NPA is a critical factor which has adversely impacted the financial sector in India. NPAs beyond a particular level becomes a matter of concern for everyone. NPAs affect the flow of credit which in turn affect the development and growth of the economy hence proper flow of credit is the need of the hour. Banks not only raise assets through new deposits but they also reuse the assets which they get from the borrowers. NPAs affects the profits earned by the banks as they have to create bigger provisions for doubtful and bad debts. Hence, the research will be performed with the aim of analyzing the impact of NPA on the profitability of the banks. The research is also conducted to analyze the impact of important financial heads on NPA.

\section{B. Scope of the Study}

The research includes the combination of NPAs of banks (private and public) which are operating in India. As observed from the literature review, very few research in which both the impact of NPA on profitability as well as impact of important financial heads on NPA has been done. So, it becomes imperative to know these aspects of NPAs in the banks.

\section{Type of Research}

The research follows the descriptive research approach. Secondary data collected from the yearly reports of banks and from RBI website will be used for the research. The relationship and impact will be calculated using correlation and regression analysis.

\section{Objective}

1. To understand the concept of NPA and its recovery through various channels.
2. To determine whether there is significant impact of Financial Head (total assets, total advances and total deposits) on NPA.

3. To determine the impact on the profitability of banks due to NPA.

\section{E. Data Collection:}

The data related to NPA of banks was collected for the period 2014-2015 to 2018-2019 from the RBI publication "Bank Wise and Bank Group-Wise Gross Non-Performing Assets, Gross Advances and Gross NPA ratio of Scheduled Commercial Banks". The data of financial heads were collected from the yearly reports of the selected commercial banks.

\section{F. Sample for the Study}

Convenience sampling was used. According to RBI data the five banks from each sector i.e. public and private, with the highest NPA were taken as sample for the research.

The public banks selected as sample are:

1. Bank of Baroda: Through an RTI, it was revealed that the NPA in this bank have increased six times between 2014 and 2019. ${ }^{[16]}$

2. SBI: Due to increasing NPAs, SBI was downgraded by the Bank of America Securities. ${ }^{[17]}$

3. Bank of India: It was having high NPA as per RBI data. $^{[19]}$

4. Punjab National bank: Due to the fraud, there was an increase in the NPAs and it also affected the performance of various other banks. ${ }^{[18]}$

5. Union Bank of India: It was having high NPA as per RBI data. $^{[19]}$

The private banks selected for study are:

1. ICICI Bank: Due to increasing NPAs, ICICI Bank was downgraded by the Bank of America Securities. ${ }^{[17]}$

2. Axis Bank: It had reported a 998 per cent jump in its NPAs over the five financial years. ${ }^{[20]}$

3. HDFC Bank: With rise in gross NPA, there has been an increase in the provisions for bad debt. ${ }^{[21]}$

4. IDBI Bank: The Bank posted huge loss in $3^{\text {rd }}$ quarter of 2019 due to rise in number of NPA cases. ${ }^{[22]}$

5. Yes Bank: The Bank posted huge loss in $3^{\text {rd }}$ quarter of 2019 due to rise in number of NPA cases. ${ }^{[23]}$ 
Website: ijetms.in Issue:3, Volume No.4, May-2020 DOI: 10.46647/ijetms.2020.v04i03.001

\section{G. Hypothesis}

$\mathrm{H}_{0}$ : "There is no significant impact of NPA and Profitability of banks."

$\mathrm{H}_{1}$ : "There is no significant individual impact of financial heads on the NPAs of banks."

$\mathrm{H}_{2}$ : "There is no significant impact of financial heads on the NPAs of banks."

\section{H. Analysis Technique}

1. Correlation Analysis: This technique is used to determine the relation between Net Profits and Net NPAs.

2. Multiple Regression: This technique is used to determine the overall as well as individual impact of financial heads on the NPAs.

\section{Limitations of the Study}

1. The profits earned by the banks is affected by various elements however in this study the only focus is on NPA.

2. There are many financial heads however we have considered only three viz. Total Assets, Total Deposits and Total Advances.

3. Time period considered for this study is five years from 2014-15 to 2018-19, thus for better results and better insights, a longer time period must be considered.

4. Based on the highest NPA data, only five banks from each sector i.e. public and private were considered for this study and rest were ignored.

\section{ANALYSIS AND INTERPRETATION}

\section{A. Relation between NPA and Profitability of Private Banks}

\begin{tabular}{|c|c|c|c|c|c|c|c|c|c|c|}
\hline \multirow[t]{2}{*}{ Year } & \multicolumn{2}{|c|}{ Axis Bank } & \multicolumn{2}{|c|}{ HDFC Bank } & \multicolumn{2}{|c|}{ ICICI Bank } & \multicolumn{2}{|c|}{ IDBI Bank } & \multicolumn{2}{|c|}{ Yes Bank } \\
\hline & Net NPA & NetProfit & NetNPA N & Vet Profit & Net NPA N & Vet Profit I & NetNPA & NetProfit & NetNPA I & Net Profit \\
\hline 2018-2019 & 11,276 & 4,677 & 3,215 & 21,078 & 13,577 & 3,363 & 14,837 & $-15,116$ & 4,485 & 1,720 \\
\hline 2017-2018 & 16,592 & 276 & 2,601 & 17,487 & 27,886 & 6,777 & 28,665 & $-8,238$ & 1,313 & 4,225 \\
\hline $2016-2017$ & 8,627 & 3,679 & 1,844 & 14,550 & 25,451 & 9,801 & 25,206 & $-5,158$ & 1,072 & 3,330 \\
\hline $2015-2016$ & 2,522 & 8,224 & 1,320 & 12,296 & 13,297 & 9,726 & 14,643 & $-3,665$ & 284 & 2,539 \\
\hline 2014-2015 & 1,317 & 7,358 & 896 & 10,216 & 6,256 & 11,175 & 5,993 & 873 & 88 & 2,005 \\
\hline Correlation & \multicolumn{2}{|c|}{-0.9493} & \multicolumn{2}{|c|}{0.9976} & \multicolumn{2}{|c|}{-0.2020} & \multicolumn{2}{|c|}{-0.3678} & \multicolumn{2}{|c|}{-0.3156} \\
\hline P-value & \multicolumn{2}{|c|}{0.01361374} & \multicolumn{2}{|c|}{0.00014427} & \multicolumn{2}{|c|}{0.74455184} & \multicolumn{2}{|c|}{0.542486838} & \multicolumn{2}{|c|}{0.604992861} \\
\hline
\end{tabular}

Table 1 Net Profit and Net NPA of Private Sector Banks from 201415 to $2018-19$

Table 1 shows the correlation of NPA and Profits of private banks. AXIS Bank (-0.9493) shows a high negative correlation. Whereas, HDFC (0.984) shows a positive correlation. While ICICI Bank (-0.2020), IDBI (-0.3678) and Yes Bank (-0.3156) show a weak negative correlation. All the banks except HDFC have negative correlation showing the inverse relation between NPA and Profits.

The p-value was obtained by applying linear regression on Net NPAs and Net profits of all the selected private banks.

Table 1 depicts that the p-value in case of Axis (0.0136) and HDFC (0.0001) is less than 0.05 suggesting the rejection of $\mathrm{H}_{0}$ hypothesis indicating that the profits of Axis and HDFC got impacted due to NPA.

\section{B. Relation between NPA and Profitability of Public Banks}

\begin{tabular}{|c|c|c|c|c|c|c|c|c|c|c|}
\hline \multirow[t]{2}{*}{ Year } & \multicolumn{2}{|c|}{ State Bank of India } & \multicolumn{2}{|c|}{ Punjab National Bank } & \multicolumn{2}{|c|}{ Bank of India } & \multicolumn{2}{|c|}{ Bank of Baroda } & \multicolumn{2}{|c|}{ Union Bank of India } \\
\hline & \multicolumn{3}{|c|}{ NetNPA NetProfit Net NPA } & \multirow{2}{*}{\begin{tabular}{|r} 
Net Profit \\
$-9,975$
\end{tabular}} & \multirow{2}{*}{$\begin{array}{r}\text { Net NPA N } \\
19,119\end{array}$} & \multirow{2}{*}{$\begin{array}{r}\text { Net Profit } \\
-5,547\end{array}$} & \multirow{2}{*}{$\begin{array}{r}\text { Net NPA N } \\
15,610\end{array}$} & \multirow{2}{*}{$\begin{array}{r}\text { Net Profit } \\
434\end{array}$} & Net NPA & \multirow{2}{*}{$\begin{array}{r}\text { Net Profit } \\
-2,947\end{array}$} \\
\hline 2018-2019 & 65,895 & 862 & 30,038 & & & & & & 20,332 & \\
\hline 2017-2018 & $1,10,855$ & $-6,547$ & 48,684 & $-12,282$ & 28,207 & $-6,044$ & 23,483 & $-2,432$ & 24,326 & $-5,247$ \\
\hline 2016-2017 & 58,277 & 10,484 & 32,702 & 1,325 & 25,305 & $-1,558$ & 18,080 & 1,383 & 18,832 & 555 \\
\hline $2015-2016$ & 55,807 & 9,951 & 35,423 & $-3,974$ & 27,996 & $-6,089$ & 19,406 & $-5,396$ & 14,026 & 1,352 \\
\hline 2014-2015 & 27,591 & 13,102 & 15,397 & 3,062 & 13,518 & 1,709 & 8,069 & 3,398 & 6,919 & 1,782 \\
\hline Correlation & \multicolumn{2}{|c|}{-0.9265} & \multicolumn{2}{|c|}{-0.7431} & \multicolumn{2}{|c|}{-0.7138} & \multicolumn{2}{|c|}{-0.7427} & \multicolumn{2}{|c|}{-0.8526} \\
\hline P-Value & \multicolumn{2}{|c|}{0.0236} & \multicolumn{2}{|c|}{0.1501} & \multicolumn{2}{|c|}{0.1757} & \multicolumn{2}{|c|}{0.1505} & \multicolumn{2}{|c|}{0.0664} \\
\hline
\end{tabular}

Table 2 Net Profit and Net NPA of the Public Sector Banks from 2014-15 to 2018-19

Table 2 shows the correlation of NPA and Profits of public banks. SBI (-0.9295), PNB (-0.7431), BOB (-0.7427), BOI ($0.7138)$ and UBI (-0.8526) show high negative correlation. This means that NPA is inversely proportional to Net Profit.

The p-value was obtained by applying linear regression on Net NPAs and Net profits of all the selected public banks.

Table 2 reveal that only in case of SBI the p-value (0.0236) is less than 0.05 suggesting the rejection of $\mathrm{H}_{0}$ hypothesis indicating that the profits of SBI got impacted due to NPA.

\section{Impact of Financial Heads on NPA of Private Bank}

\begin{tabular}{|l|r|r|r|r|r|r|}
\hline & & & & & \\
P-Value of & & & & & \\
Financial Heads & Axis & HDFC & ICICl & IDBI & Yes Bank \\
\hline Total Assets & 0.428315 & 0.148404 & 0.77829 & 0.190872 & 0.130857 \\
\hline Total Deposits & 0.484898 & 0.171233 & 0.522416 & 0.602676 & 0.570661 \\
\hline Total Advances & 0.391334 & 0.139676 & 0.37266 & 0.105866 & 0.233245 \\
\cline { 2 - 6 } & Overall & 0.357342 & 0.004768 & 0.604163 & 0.209436 & 0.087789 \\
\hline
\end{tabular}

Table 3 P-Value of Financial Heads of Private Banks obtained through Multiple Regression

Table 3 depicts that the p-value for all the individual financial heads of all the private banks $(p>0.05)$ suggesting the acceptance of $\mathrm{H}_{1}$ hypothesis i.e. the individual financial head has no significant impact on the NPAs of the banks. 
Website: ijetms.in Issue:3, Volume No.4, May-2020 DOI: 10.46647/ijetms.2020.v04i03.001

Table 3 shows that in case of HDFC (0.0047), the overall p-value i.e. when all the financial heads are taken together, $(\mathrm{p}<0.05)$ suggesting the rejection of $\mathrm{H}_{2}$ hypothesis i.e. these three financial heads together have a significant impact on the NPAs of HDFC bank.

D. Impact of Financial Heads on NPA of Public Bank

\begin{tabular}{|l|l|l|l|l|l|}
\hline & & & & & \\
\hline & & & & & \\
P-Value of & & & & \\
Financial Heads & SBI & PNB & BOI & BOB & UBI \\
\hline Total Assets & 0.064259 & 0.22252 & 0.485368 & 0.124112 & 0.877766 \\
\hline Total Deposits & 0.021597 & 0.295537 & 0.603424 & 0.097054 & 0.769894 \\
\hline Total Advances & 0.040666 & 0.739774 & 0.4145 & 0.195294 & 0.920098 \\
\cline { 2 - 7 } & 0.016758 & 0.34148 & 0.640321 & 0.182188 & 0.406809 \\
\hline
\end{tabular}

Table 4P-Value of Financial Heads of Public Banks obtained through Multiple Regression

Table 4 shows that the p-value of Total Deposits (0.02159) and Total Advances (0.040) of SBI is less than 0.05 suggesting the rejection of null hypothesis i.e. Total Deposits and Total Advances have an individual impact on the NPAs of SBI. The p-value for all the individual financial heads of other public banks $(\mathrm{p}>0.05)$ suggest the acceptance of $\mathrm{H}_{1}$ hypothesis i.e. the individual financial heads have no significant impact on the NPAs of the banks.

Table 4 shows that in case of SBI (0.0167), the overall pvalue i.e. when all the financial heads are taken together, $(\mathrm{p}<0.05)$ suggesting the rejection of $\mathrm{H}_{2}$ hypothesis i.e. these three financial heads together have a significant impact on the NPAs of SBI.

\section{v. FINDINGS AND SUGGESTION}

1. With the help of correlation analysis, it was revealed that NPA was negatively correlated with Net Profits in the selected banks except HDFC.

2. With the help of regression analysis, it was revealed that there was significant impact on Net Profits due to NPAs but only in the case of SBI, Axis and HDFC Bank.

3. In HDFC bank it's observed that Net NPA is positively correlated with Net Profit and through linear regression it was found that Net NPA has significant impact on Net Profit. However it may be ascertained that rise in NPAs may not lead to higher profits.

4. Multiple Regression results show that although the financial heads as individual variables do not have significant impact on NPAs of bank except SBI. However in SBI and HDFC bank the impact on NPA is quite significant when the financial heads are taken together.

Banks can take various measures to minimize future NPAs and be able to manage the existing ones. Some of the measures are:

1. The Reserve Bank of India should revise the monitoring system as well as the existing credit appraisal.

2. To ensure that customers do not divert their funds, the banks should regularly follow-up on their customers.

3. At regular intervals, all the loan accounts should be reviewed.

4. To overcome the flaws of credit appraisal and monitoring, banks should properly train their employees and staff.

5. Banks may resort to one-time settlement scheme/compromise settlement scheme. DRT, Lok Adalats etc. are ways through which recovery can be done. Nowadays banks are using the SARFAESI Act to manage the NPAs.

6. A proper process should be followed before giving credit.

7. Farmers often think that agricultural loans taken from banks will be waived off. Hence, the agriculturalist who can repay the agricultural credit may not come forward to repay the loans in time. Therefore the farmers in our country requires a lot of counselling and the bank officers engaged in this activity should provide necessary advice and counselling.

\section{CONCLUSION}

NPA is a critical factor which has adversely impacted the financial sector in India. NPAs affect the flow of credit which in turn affect the development and growth of the economy. The research showed that the public banks had higher NPA compared to private banks. The banks must now become proactive and should be ready to take tough measures so that it can recover from NPAs. The research also showed that NPA alone cannot be a measure for deciding/analyzing the health of a bank. For future research more banks from public and private sector can be taken. More financial heads can be considered for the research. Macroeconomic factor can also be considered for further research.

\section{References}

[1] Arasu, B., Sridevi, P., Nageswari, P., \& Ramya, R. (2019). “A Study on Analysis of Non -Performing Assets and its Impact on Profitability" in International Journal of Scientific Research in Multidisciplinary Studies, 5(6). 
Website: ijetms.in Issue:3, Volume No.4, May-2020 DOI: 10.46647/ijetms.2020.v04i03.001

[2] Bamoriya, P., \& Jain, R. (2013). NPA and Select Key Financial Heads: an Empirical study of Commercial Banks of India using Multiple Regression Modelling. Journal of Accounting and Management, 3(2).

[3] Chellasamy, D., \& Prema, A. (2018). Impact of NPA on Profitability Performance of Select Public and Private Sector Banks in India. International Journal of Economic and Business Review, 6(2).

[4] Dudhe, Chetan. (2017). Impact of non-performing assets on the profitability of banks - a selective study. The annals of the university oradea economic sciences. Tom xxvi 2017.

[5] Gulati, D. (2018). Comparative Analysis of Impact of NPAs on Profitability. International Journal of Research and Analytical Reviews, 5(2).

[6] Kandasamy, C., \& Eswaran, D. (2013). A Study on Management of Non-Performing Assets (NPAS) In New Generation Private Sector Commercial Banks in India. International Journal Of Science And Research (IJSR).

[7] Kavitha, Nachimuthu \& Muthukrishna, Veni. (2019). Impact of non-performing assets on the profitability in Indian scheduled commercial banks. African Journal of Business Management. 13. 128-137. 10.5897/AJBM2018.8683.

[8] Mishra, D., \& Pawaskar, J. (2017). A Study of Non-Performing Assets and its Impact on Banking Sector. Journal for Research, $3(1)$.

[9] Mittal, Raj \& Suneja, Deeksha. (2017). The Problem of Rising Non-performing Assets in Banking Sector in India: Comparative Analysis of Public and Private Sector Banks. International Journal of Management, IT \& Engineering. 7. 384-398.

[10] Philip, B., \& John, N. (2018). A study on the impact of NPA on the share price of banks. International Journal Of Advanced Research And Development, 3(2).

[11] Piyush, P., \& Goel, S. (2017). Measurement of Correlations (NPA and ROA) Of Different Banks and Trend Analysis of NPAs in Indian Banks. International Journal of Management, 8(6).

[12] Rathore, D., Malpani, S., \& Sharma, S. (2016). Non Performing Assets of Indian Banking System and its Impact on Economy. IOSR Journal Of Economics And Finance, 7(6).

[13] Rawlin, Rajveer \& Ramaswamy, Shanmugam \& Bhat, Vanashree. (2014). A Comparison of Key Determinants on Profitability of India's Largest Public and Private Sector Banks, European Journal of Business and Management.

[14] Singh, Ombir. (2018).An Analysis of Non Performing Assets of Indian Banks. International Journal of Research In Commerce, Economics \& Management. 6. 37-43.

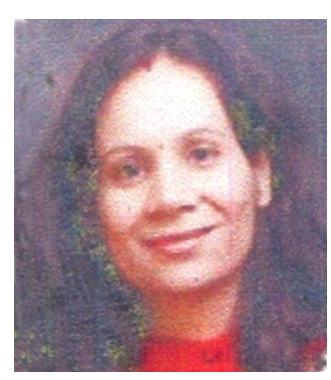

DR. RITU WADHWA
[15] Syed Ibrahim, D., \& Thangavelu, D. (2014). A Study on the Composition of Non-Performing Assets (NPAs) of Scheduled Commercial Banks in India. Journal of Finance and Bank Management, 2(1), 31-48.

[16] NPAs of BoB, Indian Bank surge multi-fold in 6 years: RTI data. (2020). Retrieved 17 May 2020, from http://economictimes.indiatimes.com

[17] BofA Securities downgrades SBI, 3 other lenders. (2020). Retrieved 17 May 2020, from http://economictimes.indiatimes.com

[18] PNB Fraud Impact on Stock Market - Effect of PNB Fraud on Equity Fund | Motilal Oswal. (2020). Retrieved 17 May 2020, from https://www.motilaloswal.com/article.aspx/1665/Howwill-the-PNB-fiasco-impact-the-equity-markets

[19] Bank Wise and Bank Group-Wise Gross Non-Performing Assets, Gross Advances and Gross NPA ratio of Scheduled Commercial Banks. (2020). Retrieved 17 May 2020, from https://dbie.rbi.org.in/BOE/OpenDocument/1608101729/OpenD ocument/opendoc/openDocument.faces? $\log$ onSuccessful=true\& shareId $=4$

[20] Private banks record 450 per cent jump in NPAs, ICICI Bank tops the list: Report. (2018). Retrieved 17 May 2020, from https://www.businesstoday.in/sectors/banks/bank-NPAs-450percent-icici-bank-hdfc-axis-yes-bank-bad-loansrbi/story/277356.html

[21] Lele, A. (2020). HDFC Bank's Q3 PBT up 15.6\% to Rs 9,901 cr; provisions rise by $37.6 \%$. Retrieved 17 May 2020 , from https://www.business_standard.com/article/finance/hdfc-bankq3-pre-tax-up-15-6-to-rs-9-901-cr-loan-loss-provisions-up-66-2120011801023 1.html

[22] IDBI Bank Q3 results: Net loss widens to ₹5,763 crore as bad loans weigh. (2020). Retrieved 17 May 2020, from https://www.livemint.com/companies/company-results/idbibank-q3-results-net-loss-widens-to-rs-5-763-crore-as-bad-loansweigh-11581422729843.html

[23] Lele, S. (2019). Yes Bank reports Rs 18,564.2-crore loss in Q3; NPAs saw a sharp rise. Retrieved 17 May 2020, fromhttps://www.business-standard.com/article/finance/yesbank-reports-rs-18-564-2-crore-loss-in-the-december-quarter120031401162 1.html

Author is Assistant Professor at Amity Business School, Amity University, Noida (U.P.) India. She 
Website: ijetms.in Issue:3, Volume No.4, May-2020 DOI: 10.46647/ijetms.2020.v04i03.001

has 17 years of teaching and research experience. She has done MBA (Finance) from GGS Indraprastha University. She has completed her doctorate in 2017 from Gautama Buddha University in area of Corporate Finance. She has 15 national and 5 international papers to her credit. Also, she has written a book titled "Strategic Financial Management". Her research Interest area is corporate finance and international financial reporting standards.

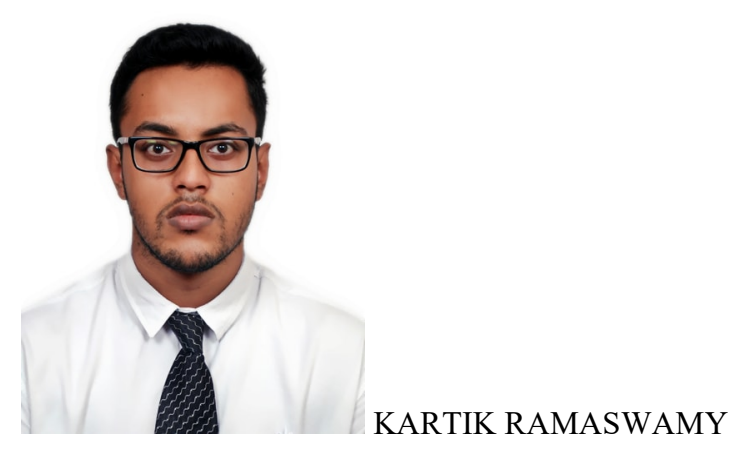

The author is currently pursuing MBA (Finance) from Amity University. He has completed his graduation in B. Tech (CSE) from the same University.He has published two research papers viz. Demographic Analysis using Predictive Algorithm (Springer) and Annapurna Vikas Patra (Shodh Sarita - UGC Care) 